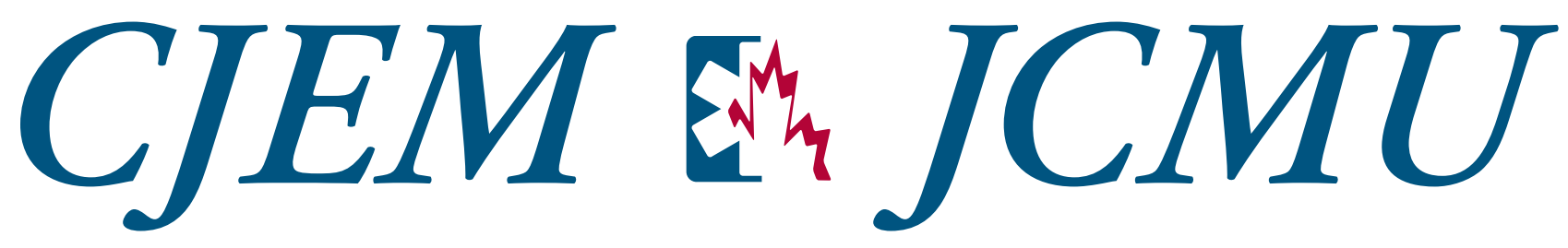

SEPTEMBER/SEPTEMBRE 2014 VOL. 16 NO. 5

\title{
Survey of Pediatric Pain Management
}

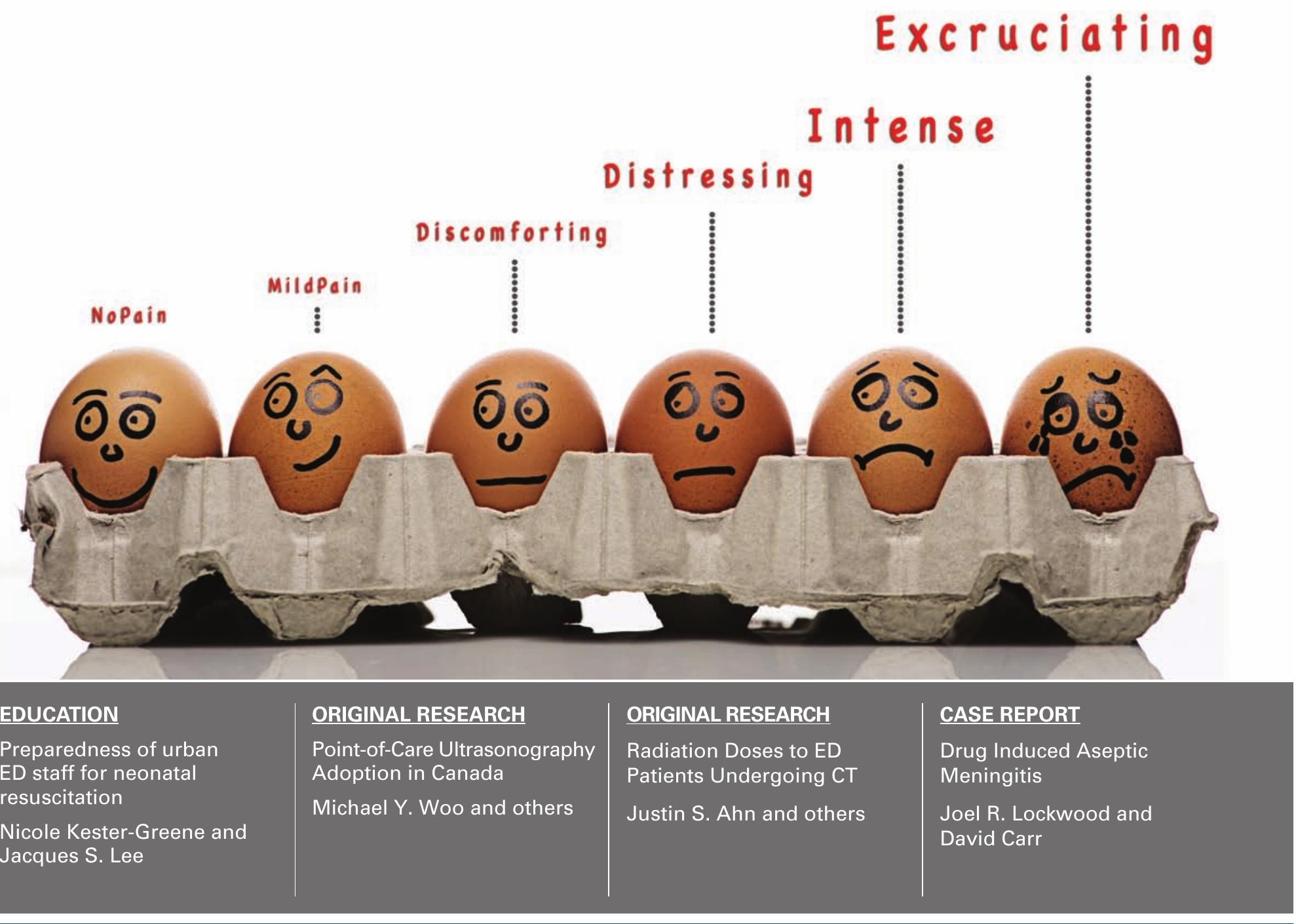

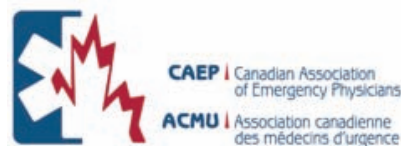




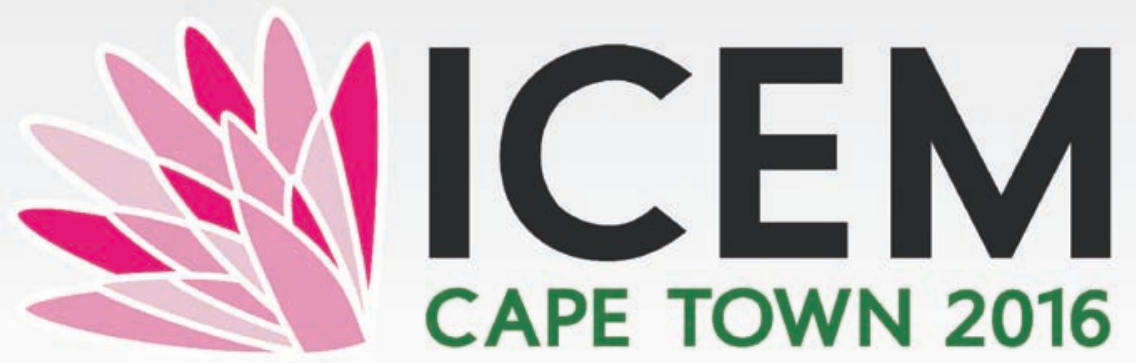

EM NOW: KNOWLEDGE, ACTION \& ACCOUNTABILITY 18-21 April 2016 • Cape Town International Convention Centre www.icem2016.org
16 TH

INTERNATIONAL CONFERENCE IN EMERGENCY MEDICINE

\begin{tabular}{|l|l|}
\hline $\mathbf{1}$ April 2015 & Abstract Submission Opens \\
\hline $\mathbf{1 8}$ July 2015 & Online Registration Opens \\
\hline $\mathbf{1}$ September 2015 & Abstract Submission Closes \\
\hline $\mathbf{1 8}$ December 2015 & Early Bird Registration Closes \\
\hline $\mathbf{1}$ April 2016 & Online Registration Closes \\
\hline
\end{tabular}

\section{CAPE TOWN SOUTH AFRICA}

*Voted the number-one City in the World to visit in 2014 by The New York Times \& The Guardian 


\section{CJEM E JCMU}

Vol. 16 , No. 5

September 2014 /

septembre 2014

cjem-online.ca

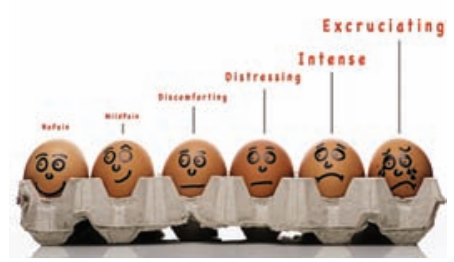

\section{About the Cover:}

In this issue, a survey of Canadian Pediatric

Emergency physicians reveals the practice variation in paediatric pain management in the emergency department.

\section{Table of Contents • Table des matières}

\section{LETTERS • CORRESPONDANCE}

343 Thyrotoxic Periodic Paralysis, $\beta_{2}$-Adrenergic Bronchodilator, and Insulin-An Interesting Interplay Subramanian Senthilkumaran, Narendra Nath Jena, Srinivasan Jayaraman, Ponniah Thirumalaikolundusubramanian

344 In Reply to "Thyrotoxic Periodic Paralysis, $\beta_{2}$-Adrenergic Bronchodilator, and Insulin-An Interesting Interplay" Chih-Jen Cheng, Shih-Hua Lin

\section{ORIGINAL RESEARCH • RECHERCHE ORIGINALE}

\section{Education}

345 Point-of-care ultrasonography adoption in Canada: using diffusion theory and the Evaluation Tool for Ultrasound skills Development and Education (ETUDE)

Michael Y. Woo, Jason R. Frank, A. Curtis Lee

\section{Pediatric EM}

352 Reported practice variation in pediatric pain management: a survey of Canadian pediatric emergency physicians

Samina Ali, Andrea Chambers, David W. Johnson, Amanda S. Newton, Ben Vandermeer, Janie Williamson, Sarah J. Curtis

\section{EM Advances}

361 Radiological errors in the Canadian Journal of Emergency Medicine James D. McEachern, David A. Leswick, Grant W. Stoneham, Karen L. Mohr, James E. Stempien

\section{EMS}

370 Assessment of older adults by emergency medical services: methodology and feasibility of a care partner Comprehensive Geriatric Assessment (CP-CGA)

Judah Goldstein, Andrew Travers, Ruth Hubbard, Paige Moorhouse, Melissa K. Andrew, Kenneth Rockwood

\section{EM Advances}

378 Chest compressions do not disrupt the seal created by the laryngeal mask airway during positive pressure ventilation: a preliminary porcine study Jestin N. Carlson, Brian P. Suffoletto, David D. Salcido, Eric S. Logue, James J. Menegazzi 


\section{Pediatric EM}

383 Postresuscitation debriefing in the pediatric emergency department: a national needs assessment

Naminder Sandhu, Walter Eppich, Angelo Mikrogianakis, Vincent Grant, Traci Robinson, Adam Cheng

\section{EM Advances}

393 Familiarity with radiation exposure dose from diagnostic imaging for acute pulmonary embolism and current patterns of practice Justin S. Ahn, Marcia L. Edmonds, Shelley L. McLeod, Jonathan F. Dreyer

\section{Pediatric EM}

405 Trends in use in a Canadian pediatric emergency department

Quynh Doan, Emerson D. Genuis, Alvis Yu

\section{KNOWLEDGE TO PRACTICE • DES}

\section{CONNAISSANCES À LA PRATIQUE}

\section{Diagnostic Challenge}

411 Diaphragmatic hernia: an unexpected cause of pseudopleural effusion

\section{Eeling Goh}

\section{ADVERTISERS' INDEX INDEX DES ANNONCEURS}

\author{
Allerject \\ A6, A7 \\ Brilinta \\ A4, A5 \\ Canadian Association of Emergency Physicians \\ C2, A5, A8, A9, A10, C3 \\ Novartis \\ C4 \\ Ross Memorial Hospital \\ A10
}

\section{Images}

413 White cerebellum sign: red flag in the emergency department Divya Singh, Amit Sharma

\section{EDUCATION • ENSEIGNEMENT}

414 Preparedness of urban, general emergency department staff for neonatal resuscitation in a Canadian setting Nicole Kester-Greene, Jacques S. Lee

\section{CASE REPORT • RAPPORT DE CAS}

421 Drug-induced aseptic meningitis secondary to trimethoprim/sulfamethoxazole: a headache to be aware of Joel R. Lockwood, David Carr

425 Anti- $N$-methyl-D-aspartate receptor (anti-NMDAR) encephalitis presenting to the emergency department with status epilepticus Brodie Nolan, Katharina Plenk, David Carr 
ACMU I Association canadienne des médecins d'urgence

\section{President / Président}

Bruce McLeod, MD

Canadian Fournal of Emergency Medicine

Fournal canadien de la médecine d'urgence

\section{Editor-in-Chief / Rédacteur en Chef}

James Ducharme, MD

McMaster University, Hamilton, Ont.

Senior Associate Editors / Rédacteurs adjoint

Riyad B. Abu-Laban, MD, MHSc

University of British Columbia, Vancouver, BC

Eddy Lang, MDCM

University of Calgary, Calgary, Alberta

Laurie J. Morrison, MD, MSc

University of Toronto, Toronto, Ont.

Marco L.A. Sivilotti, MD, MSc

Queen's University, Kingston, Ont.

Managing Editor / RÉdactrice administrative

Andrea Schaffeler, BA, BJourn

Pickering, Ont.

Assistant Managing Editor / Adjointe Á la rédactrice administrative Jennifer D. Artz, PhD

\section{EDITOR EMERITUS / RÉDACTEUR ÉMÉRITE}

Grant Innes, $M D$

University of Calgary, Calgary, Alta.

\section{AsSOCIATE Editors / RÉdACteURS ASSOCIÉs}

EM ADVANCES

Jacques S. Lee, MD, University of Toronto, Toronto, Ont.

Heather Murray, MD, MSc, Queen's University, Kingston, Ont.

Ian G. Stiell, MD, MSc, University of Ottawa, Ottawa, Ont.

CJEM JOURNAL CLUB

Jo-Ann Talbot, MD, Dalhousie University, Saint John, NB.

Community EM

David Mann, MD, Powell River General Hospital, Powell River, BC.

Diagnostic Challenge

Brian Steinhart, MD, St. Michael's Hospital, Toronto, Ont.

ED ADMINISTRATION

Christopher M.B. Fernandes, MD, University of Western Ontario,

London, Ont.

Editorials/Radical Departure

Jeffrey Freeman, MD, University of Michigan, Ann Arbor, Mich.

EDUCATION

Jonathan Sherbino, MD, MEd, St. Joseph's Hospital, Hamilton, Ont.

HUMOUR AND HUMANITY

Jeffrey Freeman, MD, University of Michigan, Ann Arbor, Mich.
INTERNATIONAL EM

Garth Dickinson, MD, University of Ottawa, Ottawa, Ont.

Methodology: The Science of EM

Editor:

Andrew Worster, MD, MSc, McMaster University, Hamilton, Ont.

Reviewers:

Andrew G. Day, MSc, Queen's University, Kingston, Ont.

Rob Stenstrom, MD, PhD, University of British Columbia, Vancouver, BC.

Garth Hunte, MD, PhD, University of British Columbia, Vancouver, BC.

Pediatric EM

Ran Goldman, MD, University of British Columbia, Vancouver, BC

Niranjan Kissoon, MD, University of British Columbia, Vancouver, BC

PHARMACOTHERAPY

Peter J. Zed, BSc(Pharm), PharmD, University of British Columbia, Vancouver, BC

Jeff Eppler, MD, Kelowna General Hospital, Kelowna, BC

REsident Issues EDITOR

Rohit Mohindra, MASc, MD, McGill University, Montreal, QC

STATE OF THE ART

Steven Brooks, MD, MHSc, Queen's University, Kingston, Ont.

TOXICOLOGY

Roy Purssell, MD, University of British Columbia, Vancouver, BC

Editors at LaRge / Rédacteurs occasionnels

Paul Atkinson, MB BCh BAO, MA, Dalhousie University \& Saint John Regional Hospital, Saint John, NB

Alix Carter, MD, MPH, Dalhousie University, Halifax, NS

Jim Christenson, MD, University of British Columbia, Vancouver, BC

Stephen Choi, MD, The Ottawa Hospital, Ottawa, Ont.

Robert S. Green, MD, Dalhousie University, Halifax, NS

James Maskalyk, MD, St. Michael's Hospital, Toronto, Ont.

Andrew McRae, MD, PhD, University of Calgary, Calgary, Alberta

Jeffrey Perry, MD, MSc, University of Ottawa, Ottawa, Ont.

Michael J. Schull, MD, MSc, Toronto, Ont.

Andrew H. Travers, BSc, MD, MSc (Epidemiol), Halifax, NS

Suneel Upadhye, MD, Hamilton, Ont

TRANSLATION / TRADUCTION

Les Traductions Corpus

\section{EDITORIAL INOUIRIES}

Send to C7EM, c/o Andrea Schaffeler, Managing Editor, Canadian Fournal of Emergency Medicine, 628 Cowan Circle, Pickering ON L1W 3K7; cjem@rogers.com

\section{SUbMissions}

Submissions to CFEM should be made at http://mc.manuscriptcentral.com/ cjem.

\section{SUBSCRIPTIONS AND ALL OTHER CORRESPONDENCE}

$C 7 E M$ is owned by the Canadian Association of Emergency Physicians

(CAEP) and printed by General Printers, on acid-free stock.

CAEP Head Office: 180 Elgin Street, Suite 808, Ottawa, ON K2P 2K3;

tel 613 523-3343; fax 613 523-0190; admin@caep.ca

Address changes: contact customercare@deckerpublishing.com. Requests for permission to reproduce items in C7EM: contact permissions@ deckerpublishing.com

\section{Publisher / Éditeur}

C7EM is owned by the Canadian Association of Emergency Physicians (CAEP). CFEM is published in January, March, May, July, September and November for CAEP by Decker Intellectual Properties. CAEP and Decker Intellectual Properties assume no responsibility or liability for damages arising from any error or omission, or from the use of any information or advice contained in the journal, including articles, editorials, case reports, reviews, media reviews, letters and advertisements. All editorial matter in
$C 7 E M$ represents the opinions of the authors and not necessarily those of CAEP, the publisher, its subsidiaries and their respective directors.

\section{Journals Manager}

Paula Mucci

Advertising / Annonces

John D. Birkby

jbirkby@andrewjohnpublishing.com 


\section{BRILINTA \\ IS COVERED \\ ON PROVINCIAL \\ FORMULARIES \\ ACROSS CANADA}

BRILINTA (ticagrelor), co-administered with acetylsalicylic acid (ASA), is indicated for the secondary prevention of atherothrombotic events in patients with Acute Coronary Syndromes (ACS) (unstable angina [UA], non-ST elevation myocardial infarction [NSTEMI] or ST elevation myocardial infarction [STEMI]) who are to be managed medically, and those who are to be managed with percutaneous coronary intervention $(\mathrm{PCl})$ (with or without stent) and/or coronary artery bypass graft (CABG).

\section{Formulary coverage}

for BRILINTA is offered in:*

British Columbia

Alberta

Saskatchewan

Manitoba

Ontario

Quebec

New Brunswick

Nova Scotia

Newfoundland and Labrador

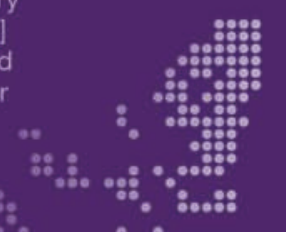

Listed under Limited Coverage, Restricted Benefit or Special Authorization, Exception Drug Status, Exception Drug Status, Limited Use, Exception Drug, Special Authorization, Exception Status Drug and Special Authorization, respectively.-9

Ticagrelor is recommended by the Canadian Cardiovascular Society in the 2012 Guidelines for the Use of Antiplatelet Therapy ${ }^{10 \dagger}$

- NSTEACS: In moderate to high risk NSTEACS patients managed with either PCI, CABG

or medical therapy alone, ticagrelor + ASA is recommended for secondary prevention

- STEMI: In STEMI patients after primary PCI, ticagrelor + ASA is recommended for

secondary prevention 
Maintenance dose ASA: Co-administration of

BRILINTA and high maintenance dose ASA

(>150 mg daily) is not recommended.

Other relevant warnings and precautions:

- Cardiac events in discontinued patients

- Bradycardic events

- Hypersensitivity, including angioedema

- Dizziness and confusion

- Discontinuation prior to surgery

- Dyspnea

- Pregnant or nursing women

- Possible increase in creatinine levels

- Uric acid increase

For more information:

Consult the Product Monograph at azinfo.ca/ brilinta/pm274 for important information regarding adverse reactions, drug interactions and dosing information not discussed in this piece. The Product Monograph is also available by calling AstraZeneca Canada at 1-800-668-6000.11

References: 1. British Columbia Ministry of Health. Available from: http://www.health.gov.bc.ca/pharmacare/sa/criteria/ 2. Alberta Health Interactive Drug Benefit List. Available from: https://www.ab.bluecross.ca/dbl/idbl_main1.html. Accessed October 1, 2013. 3. Government of Saskatchewan Drug Plan and Extended Benefits Branch. Available from: November 2, 2012. 4. Manitoba Health. Available from: http://www.gov.mb.ca/health/mdbif/edsnotice.pdf. Accessed January 21, 2013. 5. Ontario Drug Benefit Formulary/
Comparative Drug Index. Available from: http://www.health. gov.on.ca/en/pro/programs/drugs/formulary/41 update at_20130419.xls. Accessed April 30, 2013. 6. Régie de l'assurance maladie du Québec. Available from:

\section{ROADSHOWS CAEP I ACMUE}

AIME Airway Intervention \& Management in Emergencies September 5, 2014 - Truro NS (SOLD OUT) September 6, 2014 - Truro NS (SOLD OUT) September 25, 2014 - Whistler BC (SOLD OUT)

October 6, 2014 - Vernon BC November 12, 2014 - Quebec City QC* November 13, 2014 - Quebec City QC* December 10, 2014 - Montreal QC December 11, 2014 - Montreal QC February 18, 2015 - Halifax NS April 7, 2015 - Montreal QC April 8, 2015 - Montreal QC

\section{EDTU: Emergency Department}

Targeted Ultrasound

(Now 2 Day Course, Updated Curriculum)

November 1 \& 2, 2014 - Toronto ON (SOLD OUT)

November 1 \& 2, 2014 - Vancouver BC

December 6 \& 7, 2014 - Montreal QC

RB: Risky Business - Clinical Decision Making in Emergency Medicine November 25, 2014 - Sudbury ON

\section{ID: Infectious Disease Management in Emergency Medicine October 16, 2014 - Regina SK}

\section{REGISTER NOW!}

*In conjunction with a conference, registration through the respective conference, not via CAEP.ca. Contact CAEP for details. 


\section{A VOJCE}

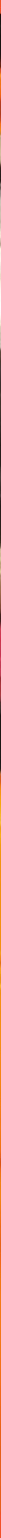

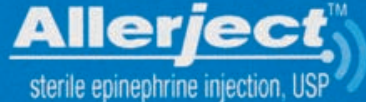

Auto-injector

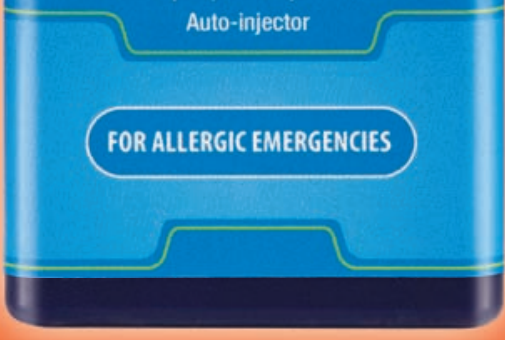

Allerject ${ }^{\text {Ti }}$ epinephrine auto-injector:

It Talks! The first and only epinephrine injector with audio instructions* Easy-Use Design! Allerject ${ }^{\mathrm{TM}}$ was designed to be easy to use Compact! Fits in your palm...designed for portability Lights Up! LED flashes when injection is complete

${ }^{\star}$ Comparative clinical significance unknown.

\section{Living with the risk of anaphylaxis...}

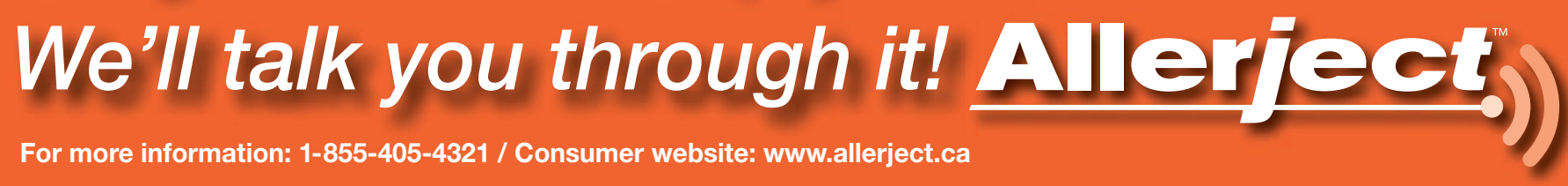


Indications and clinical use

Allerject ${ }^{\mathrm{TM}} 0.3 \mathrm{mg}(0.3 \mathrm{~mL}$ Epinephrine Injection, USP, 1:1000) and Allerject ${ }^{\mathrm{TM}} 0.15 \mathrm{mg}(0.15 \mathrm{~mL}$ Epinephrine Injection, USP, 1:1000) are indicated for the emergency treatment of anaphylactic reactions in patients who are determined to be at increased risk for anaphylaxis, including individuals with a history of anaphylactic reactions. Selection of the appropriate dosage strength is determined according to patient body weight.

Allerject $^{\mathrm{TM}}$ is intended for immediate self-administration for the emergency treatment of severe allergic reactions (Type I). Following treatment of anaphylaxis, the patient must seek immediate medical attention.

\section{Contraindications:}

No absolute contraindications

\section{Relevant warnings and}

\section{precautions:}

- Inject into the outer thigh

- Use of more than 2 sequential doses

- Use in patients with cardiogenic traumatic, or hemorrhagic shock; cardiac dilation; cerebral arteriosclerosis; cardiac arrhythmias; coronary artery or organic heart disease; hypertension or hyperthyroidism

- Patients with organic brain damage or Parkinson's disease

- Patients with narrow-angle glaucoma

- Use in diabetic patients

- Patients with sulfite sensitivity

- Patients with concomitant asthma

\section{For more information:}

Please consult the

Prescribing Information at:

products.sanofi.ca/en/allerject.pdf for important information relating to adverse reactions, drug interactions and dosing information which has not been discussed in this piece.

The Prescribing Information is also available by calling us at: 1-800-265-7927.

Manufactured for

sanofi-aventis Canada Inc.,

Laval, Quebec, Canada H7V OA3

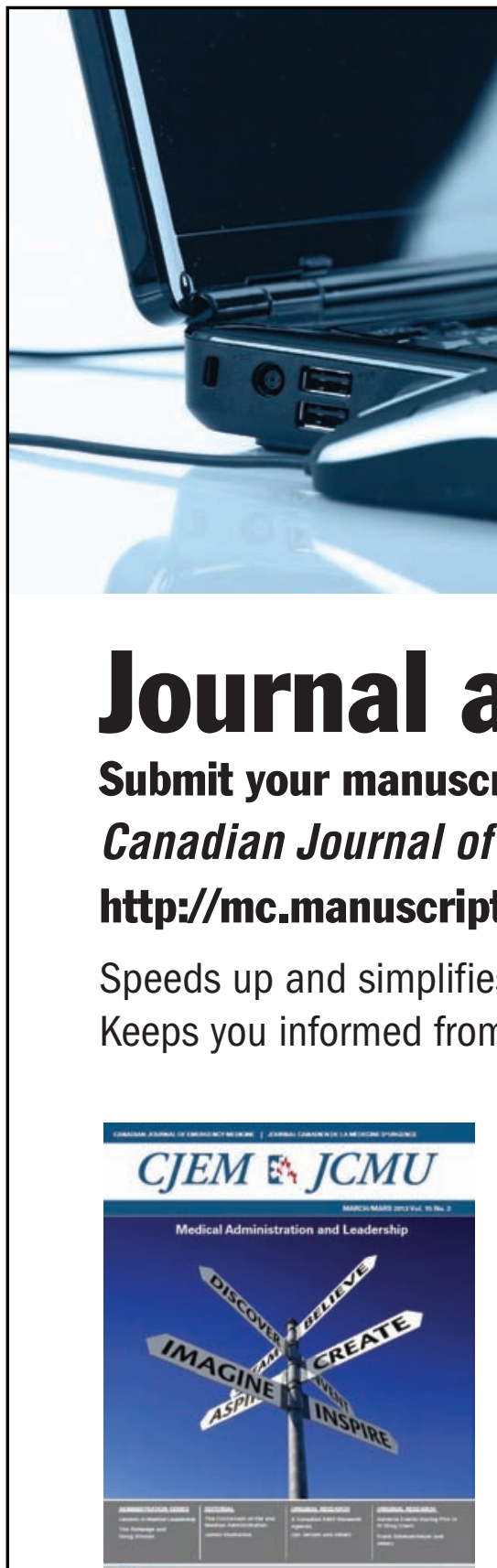

$5=$

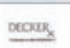

THOMSON

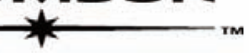

SCHOLARONE ${ }^{\oplus}$ MANUSCRIPT CENTRALTM

Manuscript Central ScholarOne are registered trademarks of Thomson Scientific.

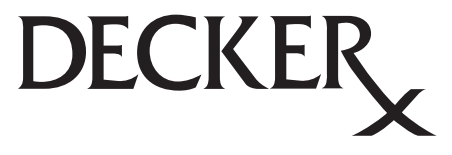

www.deckerpublishing.com
Submit your manuscripts on Manuscript Central. It's the online tool that makes submission easy and expedites the peer review process. You can even track the progress of your manuscript through to acceptance. 
Research is important in all areas of emergency medicine. Physicians, fellows, and residents working in diverse academic, non-academic, community, and rural settings are encouraged to submit CAEP Research Grant proposals.

\section{IMPORTANT RESEARCH GRANT PROPOSAL DATES}

Electronic submission opens: Monday, September 15, 2014 at 09:00 Eastern

Electronic submission closes: Thursday, October 30, 2014 at 23:59 Eastern (no exceptions)

Notification: January 30, 2015

\section{PREREQUISITES FOR SUBMITTING GRANT PROPOSALS}

$\checkmark$ The Principal Investigator (PI) and Supervisor (for Residents and Fellows only) must be current CAEP members at the time of application. Proposals will not be reviewed if CAEP membership cannot be verified.

$\checkmark$ Only CAEP members can receive grant funds.

$\checkmark$ The PI must be $<8$ years beyond postgraduate training.

$\checkmark$ A letter of support from Resident's/Fellow's Supervisor (or Department Head) must be included with the proposal.

\section{GRANT SUBMISSION PROCESS}

- Complete submission instructions are posted on the 2015 CAEP Abstract Central and CAEP Research webpages. (http://caep2015researchcompetitions.abstractcentral.com and http://caep.ca/ResearchOverview)

- Proposals are limited to 15,000 characters for abstract, research in depth, timeline and impact sections.

- References, research data collection tool, budget, CV, and support letter are not included in the character count.

The electronic submission process includes the following sections:

- Structured Research Abstract

- $\quad$ Research In Depth

- Timeline and Impact

- References

- Research Data Collection Tool

- Detailed Budget and Justification

- Curriculum vitae (CV) of the Principal Investigator

- Accompanying Support Letter from the Responsible Supervisor or Department Head

\section{GRANT PROPOSAL REVIEWS}

Grants are peer reviewed by three CAEP Grant Reviewers using a standardized evaluation form. Reviewers are blinded to the author's name and institutional affiliations. Reviewers will not evaluate grants from their own province, and conflict of interest declarations are provided to each reviewer. Reviewers consider:

- Relevancy to emergency medicine

- Methodological quality

- Originality of the topic and methodology

- Level of training

- Ability to complete the proposed study

\section{GRANT FUNDING PROVISIONS}

A CAEP Grant for an individual project will not exceed $\$ 5000$. CAEP financial support cannot be a supplement to other funding sources or used for meeting registration, travel, or equipment purchases. 